\title{
SHORT TANDEM REPEATS (STRS) AS A PRIMARY METHOD FOR PERSONAL IDENTIFICATION (A case report)
}

\author{
Johannis F. Mallo \\ Department of Forensic Medicine and Medicolegal \\ Medical Faculty - University of Sam Ratulangi Manado \\ e-mail: mallojohannis@gmail.com
}

\begin{abstract}
Abstrak: Mayat seorang perempuan tak dikenal yang ditemukan di daerah Malalayang dibawa oleh polisi ke Rumah Sakit Umum Pusat Prof.dr.R.D Kandou. Mayat tersebut telah mengalami proses awal pembusukan. Selain itu pihak kepolisian mengalami kesulitan untuk menentukan identitas mayat tersebut serta menemukan keluarganya. Demi pengungkapan kejadian yang menyebabkan kematian perempuan tak dikenal ini, terlebih dahulu polisi harus dapat menentukan identitas mayat. Melalui data medis yang dikumpulkan dari proses autopsi forensik, digabungkan dengan daftar orang hilang yang dibuat oleh kantor kepolisian Sektor Malalayang dan Kepolisian Kota Besar Manado, ditemukan kecocokan data yang merujuk pada seorang perempuan yang dilaporkan hilang oleh keluarganya. Polisi kemudian meminta pemeriksaan identifikasi melalui metode analisis DNA untuk membandingkan DNA mayat dengan DNA individu-individu yang mengaku sebagai keluarga korban. Pada saat autopsi forensik, diambil sampel tulang padat iga kanan dan kiri sepanjang $10 \mathrm{~cm}$ dari mayat. Sebagai pembanding diambil apusan mukosa pipi dan $2 \mathrm{cc}$ darah tepi dari individu-individu yang diduga ayah dan adik kandung dari mayat yang ditemukan. Proses ekstraksi, kuantifikasi, PCR, dan proses analisis akan dilakukan di Pusat Laboratorium Forensik Kepolisian Republik Indonesia.
\end{abstract}

Kata kunci: identitas mayat, identifikasi DNA, PCR, STR

\begin{abstract}
Ms X's corpse was brought to Prof.R.D Kandou general hospital by police officers. Ms X was found in Malalayang without any identity attached to her body. Her body had begun to decompose, and the police had difficulties in finding Ms X's relatives. In order to uncover the case behind Ms X's death, the police had to first discover the true identity of Ms X. Medical data was acquired during an autopsy, and from a list that the police made, a match was found in a report of missing persons when two data were compared. The Police requested a paternity DNA examination in order to have a positive identification of Ms X. During the forensic autopsy of Ms X, $10 \mathrm{~cm}$ of left and right costal compact bones were obtained. Buccal swabs were made and $2 \mathrm{cc}$ of peripheral blood were taken, each from the suspected father and a suspected sister of Ms X. Extraction, quantification, PCR, and the analysis was made at Pusat Laboratorium Forensik Kepolisian Republik Indonesia the main Police Forensic Laboratory of Indonesia. PCR involves 13 to 15 of nuclear STR loci, and the analyzing process of the samples involves comparing the 13 to 15 nuclear STR loci of the 3 people. If a match is found with $99 \%$ accuracy, then identification is verified. The Paternity Index indicates the greatest possibility that the suspected father is the real father of Ms X, compared to other males in the Asian / Indonesian Population.1
\end{abstract}

Keywords: corpse identity, DNA identification, PCR, STR 


\section{IDENTIFICATION}

In reality, a person on his deathbed, usually wants to be close to his loved ones. However, this wish often is otherwise. In this era of advanced communication and mobilization, many people travel from one place to another, resulting in one dying far away from their loved ones, or any one that can positively identify them. It is also a fact that when loved one is said to have died, we want to have a certain kind of assurance of that fact. This assurance will allow the family to properly grieve. On the other hand without this assurance these families will always be in a state of doubt, uncertainty, or complete rejection of the fact. These facts give us a clear reason of what identification means to a family that has been left behind, apart from the legal verifications that must be fulfilled.

Identification involves processes to identify people by comparing two or more valid data. Personal identification methods are many, but there are three methods that were considered as primary identification methods. In simple terms, primary identification methods mean that if the result from one of these three methods is a match, then we can say that the person is identified. These three methods are: finger prints, dental identification, and DNA identification.

DNA identification can only be considered as the primary identification method if the method of examination can exactly identify one individual. One of these methods of examination is the Short Tandem Repeats (STRs), a method that uses several non-protein expression loci in human DNA to identify a person. STRs can analyze even if the amount of the sample is very little. This method has been standardized by the FBI to be used in all parts of the United States of America as a method of DNA identifi- cation. STRs uses a Polymerase Chain Reaction (PCR) to amplify the amount of specific loci, so even a degraded, or small amount of sample can be analyzed.2,3

PCR is an enzymatic process where specific areas from DNA are replicated again and again to give us many copies from a certain sequence. Thermal cycling typically involves three different temperatures that are repeated over and over again 25-35 times. At $94^{\circ} \mathrm{C}$, the DNA strands separate or 'denature'. At $60^{\circ} \mathrm{C}$, primers bind or 'anneal' to the DNA template, and target the region to the amplified. At $72^{\circ} \mathrm{C}$, the DNA polymerase extends the primers by copying the target region using the deoxynucleotide triphosphate building blocks. Theoretically, after 32 cycles, one specific locus will have 1073741824 copies. This is why PCR based methods like STRs can be used to analyze a tiny amount of sample found in a crime scene. Small base pair sequence number constructing STRs or mini STRs make it possible for this method to analyze a certain grade of degraded sample. 3

STRs and other PCR based methods of identification are now very popular because of the time efficiency that they provide. The time required to obtain a result with PCR-based typing is much shorter compared with the other typing techniques. In comparison, RFLP methods need 6-8 weeks with radioactive probes, or one week with chemiluminescent probes, but only 1-2 days are needed in PCR-based methods. 4

\section{CASE}

Ms X's corpse was brought to Prof. dr. R.D Kandou General Hospital by police officers. Ms X was found in Malalayang without any identity attached to her body. Her body had undergone an early 
decomposition process, and the police had difficulties in finding $\mathrm{Ms} \mathrm{X}$ 's relatives. Ms X was a 30 to 35 year old female, Mongoloid race, wavy black hair, without tattoo or any specific marks on her body. After consulting a forensic specialist, the Chief of the Police Sector Office of Malalayang issued a letter requesting a DNA examination for identification purposes. The police brought an autopsy request, and the autopsy was carried out two days later. In the autopsy, $10 \mathrm{~cm}$ of left and right costal compact bones were taken, and sealed as samples.

Finger prints taken from Ms X were analyzed, but no match could be found in the police database. Dental charts from the autopsy were also analyzed by the police, albeit still no match could be found. In coordination with the Police office, mass media, and the hospital forensic department, Ms X's facial photographs were provided to the mass media, hoping that some one would recognize Ms X. A week after the autop-sy, the police had a strong indication that Ms X was actually Ms J. Medical data from the autopsy had a large proportion of compatibility to $\mathrm{Ms}$ J's physical appearance and other ante mortem data collected from Ms J's relatives. The police, after coordinating this information with the forensic specialist, brought Ms J's suspected father and sister to Bhayangkara hospital. From Ms J's father and sister, were taken buccal swabs, and 2 cc each of peripheral blood was kept in an EDTA vial. As a method of precaution, 10 strands of hair, including the hair root were also taken from both suspected father and sister of Ms.J. All samples were put in separate envelopes, and then sent to Puslabfor Mabes POLRI. There the samples were extracted, quantified, and underwent the PCR process before they were analyzed by using the analysis machine based on STRs method standards.

In this article, there are still some facts that are still unknown; thus, this case is still under police investigation. Further data can be confirmed at the writer's office at the Department of Forensic Medicine and Medicolegal of the Medical Faculty, University of Sam Ratulangi.

\section{DISCUSSION}

Handling an unidentified human corpse has specific requirements that may not be present when handling a deceased person with a clear identity, or with relatives or their loved ones at their side. Identification will become the main issue in forensic examination of these cases. With proper identification, the case behind the death of the deceased can be uncovered. In other words, it will also mean that a poor identification will always lead to the magnified risk of error in unveiling the perpetrator of a case. Incorrect identification can lead to false arrest and prosecution, putting innocent people behind bars while allowing the perpetrator to go free.

In forensic identification, there are 9 methods of identification, consisting of three primary identification methods and 6 secondary identification methods. All of these methods apply the basic principle of identification, which is to compare two or more data. The recent trend for personal identification is DNA identification. More cases were being solved by using this method, considering that this method is becoming more affordable and time efficient.

In this case, before getting the DNA identification, the police must have a lead about who the deceased is. From 
this lead, the police then make a list of the suspected people, as blood relations of the person they want to identify. With no data to be compared, DNA data from the deceased will not be enough to make an individual identification.

Table 1. DNA Sampling Reference2

\begin{tabular}{ll}
\hline Material & Reference \\
\hline Bone & Gill et all (1994), \\
& Idries AM et al \\
& $(2008)$ et all \\
Budowle et & $(1995)$ Idries AM \\
& et al (2008) \\
Hair with hair root & Higuchi et all \\
& $(1988)$, Idries AM \\
& et al (2008) \\
\hline
\end{tabular}

Preservation of samples taken must be done carefully and according to the procedure. Many degraded or contaminated samples come from bad pack-aging. Samples should be packaged in paper envelopes or paper bags after drying. Plastic bags should be avoided because water condenses in them, especially in areas of high humidity, and water can speed the degradation of DNA molecules. Packages should be clearly marked with a case number, item number, collection date, and initialed across the package seal in order to maintain a proper chain of custody. 5

In a few cases, the presence of PCR inhibitors such as heme, melanin, polysaccharides, bile salts, textile dyes, and other substances, hinder the PCR process resulting in a loss of the alleles from the larger sized STR loci, or even a complete failure of all loci. PCR inhibittors should be removed or reduce the PCR effects by one or more of the following solutions. The genomic DNA template may be diluted, which also dilutes the PCR inhibitor, and reampli- fied in the presence of less inhibitors. Alternatively, more DNA polymerase can be added to overcome the inhibitors. With this approach some fraction of the Taq polymerase binds to the inhibiting molecules, and removes them from the reaction. So the rest of the Taq can do its job and amplify the DNA template. 5

A forensic specialist again will be needed to confirm the conclusion of the examination after obtaining the results of the examination. This conclusion must also consider mutation, contamination, stochastic effect, racial variation, and legal issues. If all steps of identification are done with great scrutiny, the accuracy of this identification will be unmatched by other primary identification methods available today. 6

\section{CONCLUSION}

Identification is one of the main issues in forensic examination. The identification shares the same portion of importance, maybe even more, compared to the determination of the cause of death it self. STR is one of the many methods in DNA examination in terms of personal identification available in Indonesia nowadays. With great scrutiny, the accuracy of this identification method will be unmatched even by other primary identification methods available today.

\section{REFERENCES}

1. Idries AM, et al. Peran Ilmu Kedokter-an Forensik dalam proses penyidikan. Jakarta: Sagung Seto, 2008. Page : $190-210$.

2. Inman K, Rudin N. An Introduction to Forensic DNA Analysis. Florida: CRC Press; 1997. p. 4 -138.

3. Butler JM. Forensic DNA typing. Biology \& technology behind STR markers. Barcelona: Academic 
Press; 2001. p 16-165

4. Kristanto E, Untoro E, Atmadja DS. The use of X-STR analysis in person-al identification. Jogjakarta: Pertemuan ilmiah tahunan PDFI. September 2006.
5. Butler JM. Forensic DNA typing. 2nd edition. Biology, technology and genetics of STR markers. Philadelphia: Elsevier. 2005 : 33-63.

6. Owen D. Hidden Evidence. Hongkong: Periplus; 2000. p 200 - 17. 